DOI: $10.2478 /$ v.10169-010-0019-4

\title{
SIMPLE PREQUALIFICATION MODELS
}

\author{
E. PLEBANKIEWICZ ${ }^{1}$
}

\begin{abstract}
The selection of a contractor is one of the most important among decisions made by the owner of a construction. The application of the prequalification procedure enables the selection of the most competent tenderers. Various mathematical models are helpful in carrying out prequalification procedure. In the paper, some selected mathematical models are briefly characterized and model based on the theory of fuzzy sets is offered. The applied model takes into consideration the owner's various objectives, as well as different evaluation criteria. The results of the sensitivity analysis of the model are also presented. Part of a computer software applying an earlier presented prequalification mathematical model is described.
\end{abstract}

Key words: construction contractor, prequalification, fuzzy sets.

\section{INTRODUCTION}

Although the basic criterion for selecting a tender for construction works is price, the owners more and more often value the choice of a competent contractor. It is especially important in big projects. In orders announced by private owners, as well as in big international tenders, the prequalification procedure often occurs as a pre-tender selection of contractors.

Two types of prequalification can be distinguished. Prequalification may suggest grouping of the most suitable contractors for realization of a definite kind of projects (as a rule taking into consideration a chosen factor, e.g. having special equipment to do a specific kind of works). As a result it leads to forming a prequalification list ("standing list"). In such a case only contractors from the list can apply for a given project. Such lists are formed in many countries by different state organizations, big owners, and also by smaller private owners [1]. Prequalification may also mean selecting a group of contractors most suitable to compete for a particular project - the so called "per project". Such selections are often supported by mathematical models.

The aim of the paper is to present selected prequalification models, among them a model adjusted to the needs of Polish owners, built on the basis of fuzzy sets theory.

\footnotetext{
${ }^{1}$ Division of Construction Technology and Management, Cracow University of Technology, Warszawska 24, 31-155 Kraków, Poland, e-mail: eplebank@ izwbit.pk.edu.pl
} 


\section{Problem with constructing the PReQualificAtion Model}

Building a model comprising all conditions of prequalification process is not an easy task. In evaluation of a contractor, numerous criteria are taken into account, which, in turn, are characterized by the right subcriteria. In many countries there were many researches carried out on the criteria used by construction owners - Banaitienë and Banaitis [2], Jennings and Holt [3], Mitkus and Trinkúnienë [4], Plebankiewicz [5], Russell et al. [6], Singh and Tiong [7], Waara and Brochner [8].

Evaluation of many criteria is subjective and ambiguous in meaning, e.g. "contractor's reputation" is important in evaluation. It is also not an easy task to determine a single common scale of evaluation for all the criteria.

The objectives which an owner sets in a given project are essential. There are some objectives mentioned in literature which most construction projects aim at, these are: time, cost, and quality of works. Depending on different factors, first of all the purpose of the project to which an owner may attach different significance to these objectives, e.g. in the case of prestigious building, its quality is most important, the cost being of less importance. However, in the case of a building meant for sale, its quality can be less significant than its cost or time of realization.

In the process of prequalification, evaluation is carried out by a group of decisionmakers appointed by an owner. The group consists of specialists from different branches. They are usually employed by an owner, but in some cases they may come from outside and may evaluate the position and reputation of a constructor on the market. Thus, there is an additional problem of taking into consideration the model of evaluation of numerous decision-makers.

\section{Models of SIMPLE PREQUALIFICATION}

The simplest and used most often in practice is the dimensional weighting model. Its application in prequalification problems and all possible modifications were described by Jaselskis and Russell [9]. An owner chooses the criteria and their importance. Each contractor is evaluated on a set scale according to the assumed criteria. The final evaluation of the $k$ contractor can be written in the following formula [10]:

$$
O C_{k}=\sum_{i=1}^{n}\left(K_{i}\right)\left(W_{i k}\right)
$$

where: $n$ - number of criteria, $K_{i}$ - weight of the criterion $i, W_{i k}$ - a mark given to a contractor kaccording to criterion $i$.

Linear model described by Russel, among others, [11], apart from the main criteria, takes also into consideration some sub-criteria characterizing them. Computer software 
QUALIFIER-1 [12] was designed as an aid in using the model. The evaluation of the contractor in a linear model can be written as:

$$
O C_{k}=\sum_{i=1}^{n} K_{i} \sum_{j=1}^{m_{i}}\left(K_{i j}\right)\left(W_{i j k}\right),
$$

where: $n$ - number of main criteria, $m$ - number of subcriteria ascribed to criterion $i, K_{i}$ - weight of the criterion $i, K_{i j}$ - weight of the subcriterion $j$ assigned to criterion $i, W_{i j k}$ - evaluation assigned to the contractor $k$ according to subcriterion $j$, assigned to criterion $i$.

Models similar to the linear model are those taking into consideration many variations of the evaluation [11]. Criterion evaluation in these models is considered as the random variable with probability assigned to it. Two cases were detailed;

1) with normally assumed distribution,

2) with assumed $\beta$-PERT distribution.

In the first case evaluation of contractor $k$ according to criterion $j$, is an expected value of random variable and can be defined by the formula:

$$
W_{i k}=\sum_{j=1}^{m}\left(P_{j i k}\right)\left(W_{j i k}\right),
$$

where: $m$ - number of evaluations of a given criterion, $P_{j i k}$ - probability of evaluation $i$ of contractor $k$ according to criterion $j$ occurrence (probability sum of all evaluations of a given criterion equals 1.0), $W_{i j k}$ - evaluation $i$ of contractor $k$ according to criterion $j$.

Then, total, overall evaluation of contractor $k$ can be obtained as in Eq. (3.1), but taking into consideration Eq. (3.3).

In the second case, three evaluations are taken into consideration: optimistic, modal, and pessimistic. The value of random variable (evaluation of contractor $k$ according to criterion $j$ ) has the form of:

$$
W_{i k}=\frac{a+4 m+b}{6},
$$

where: $a$ - optimistic evaluation, $m$ - most probable evaluation (modal), $b$ - pessimistic evaluation.

Complete, total, evaluation of contractor $k$ can be obtained as in Eq. (3.1), but taking into consideration (3.4).

\section{Model USING THE AHP}

Some authors have formed prequalification models by using the Analytical Hierarchy Process (AHP) [13]. Such models were developed by Al-Harbi [14], Fong and Choi [15], Mahdi et al. [16]. In this paper, the model created by Al-Harbi [14] is presented. 
In the discussed model the hierarchy of the problem can be developed as shown in Fig. 1.

Level 1: Goal

Level 2: Criteria

Level 3: Contractor

\section{Selecting the most suitable contractor}

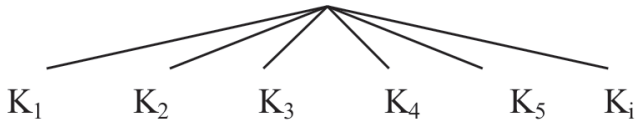

$\begin{array}{llllll}\mathrm{W}_{1} & \mathrm{~W}_{1} & \mathrm{~W}_{1} & \mathrm{~W}_{1} & \mathrm{~W}_{1} & \mathrm{~W}_{1} \\ \mathrm{~W}_{2} & \mathrm{~W}_{2} & \mathrm{~W}_{2} & \mathrm{~W}_{2} & \mathrm{~W}_{2} & \mathrm{~W}_{2} \\ \mathrm{~W}_{3} & \mathrm{~W}_{3} & \mathrm{~W}_{3} & \mathrm{~W}_{3} & \mathrm{~W}_{3} & \mathrm{~W}_{3} \\ \mathrm{~W}_{4} & \mathrm{~W}_{4} & \mathrm{~W}_{4} & \mathrm{~W}_{4} & \mathrm{~W}_{4} & \mathrm{~W}_{4} \\ \mathrm{~W}_{\mathrm{n}} & \mathrm{W}_{\mathrm{n}} & \mathrm{W}_{\mathrm{n}} & \mathrm{W}_{\mathrm{n}} & \mathrm{W}_{\mathrm{n}} & \mathrm{W}_{\mathrm{n}}\end{array}$

Fig. 1. Hierarchy of the problem.

Rys. 1. Drzewo decyzyjne

For each criterion the following operations are carried out:

1. The pair-wise comparison matrix is obtained,

\begin{tabular}{cccccc}
\hline$K_{i}$ & $W_{1}$ & $W_{2}$ & $W_{3}$ & $W_{4}$ & $W_{n}$ \\
\hline$W_{1}$ & 1 & $W_{12}$ & $W_{13}$ & $W_{14}$ & $W_{1 n}$ \\
$W_{2}$ & $W_{21}$ & 1 & $W_{23}$ & $W_{24}$ & $W_{2 n}$ \\
$W_{3}$ & $W_{31}$ & $W_{32}$ & 1 & $W_{34}$ & $W_{3 n}$ \\
$W_{4}$ & $W_{41}$ & $W_{42}$ & $W_{43}$ & 1 & $W_{4 n}$ \\
$W_{n}$ & $W_{n 1}$ & $W_{n 2}$ & $W_{n 3}$ & $W_{n 4}$ & 1
\end{tabular}

1. Synthesized matrix is performed,

2. Priority vector is calculated,

3. Consistency ratio is calculated,

4. $\lambda_{\max }-$ maximum eigenvalue is calculated,

5. Consistency index CI is calculated,

6. Consistency ratio $\mathrm{CR}$ is calculated.

Operations carried out in points $2-7$ allow to check matrix consistency. As the value of $\mathrm{CR}$ is less than 0.1 , the judgments are acceptable.

The next step is to determine the pair-wise comparison matrix for criteria:

\begin{tabular}{cccccc}
\hline & $K_{1}$ & $K_{2}$ & $K_{3}$ & $K_{4}$ & $K_{i}$ \\
\hline$K_{1}$ & 1 & $K_{12}$ & $K_{13}$ & $K_{14}$ & $K_{1 i}$ \\
$K_{2}$ & $K_{21}$ & 1 & $K_{23}$ & $K_{24}$ & $K_{2 i}$ \\
$K_{3}$ & $K_{31}$ & $K_{32}$ & 1 & $K_{34}$ & $K_{3 i}$ \\
$K_{4}$ & $K_{41}$ & $K_{42}$ & $K_{43}$ & 1 & $K_{4 i}$ \\
$K_{i}$ & $K_{i 1}$ & $K_{i 2}$ & $K_{i 3}$ & $K_{i 4}$ & 1
\end{tabular}


Subsequently the operations points 2-7 are carried out for the pair-wise comparison matrix for the criteria.

As a result these operations allow to determine the final evaluation and the ranking of contractors.

A detailed description of the models, as well as its usage, can be found in [17].

\section{OTHER MODELS}

Among other models of the evaluation of contractors, the model making use of expert system is worth consideration. The model and the programme (QUALIFIER 2) facilitating its usage was described in [18]. On several occasions, artificial neural networks were used to build a prequalification model. Such models were worked out by, among others, Lam et al. [19], Khosrowshahi [20] and Elazouni [21].

Problem of the selection of contractor is a multi-criteria problem. Many multi-criteria techniques are proposed and applied for the solution of such problems - Zavadskas and Vilutiene [22], Zavadskas et al. [23], Zavadskas et al. [24], Jaśkowski [25]. Brauers et al. [26], Ginevičius and Podvezko [27], Mitkus and Trinkuniene [28], Turskis [29], Zavadskas et al. [30], Zavadskas et al. [31] investigated the assessment of construction firms and contractors evaluation problems.

\section{Contractor PREQualification MOdel USING FUZZY SETS}

Aiming at quantification of the values, so far considered as non-measurable, resulted in the sixties of the $20^{\text {th }}$ century in forming a fuzzy sets theory and its wide application in decision making. Thanks to this theory, decision makers can, among others, evaluate contractors in the form of linguistic variables, later on converted into fuzzy numbers. Fuzzy sets theory is very useful in searching for the solutions of problems which include elements of human subjectivism, such as evaluation of contractors competence. The basic aim of fuzzy sets theory is to represent the existing inaccuracies occurring in some expressions of the natural language. Many authors think that combining the methods of representation of incomplete information with the theory of fuzzy sets, representing inaccurate information, can fully and in a natural way describe the real world phenomena. A formal description of the theory of fuzzy sets was introduced in 1965 by Zadeh [32] and he is considered as the author of this theory.

A fuzzy set is characterized by its membership function, which represents numerically the degree to which an element belongs to a set. Unlike conventional (crisp) sets theory, where objects are either in or out of a set, fuzzy sets theory allows objects to partially belong to a set.

Fuzzy sets were for the first time used to build a contractor selection model by Nguyen [33]. He proposed a procedure of choosing a bidder taking into consideration 3 
criteria: cost, presentation of bid information, and past experience, as well as different scenarios of a construction owner's preferences.

An interesting prequalification model, based on fuzzy sets, was presented by Singh and Tiong [34]. The model allows to consider different types of criteria and characterize them as subcriteria. It admits subjective evaluations of numerous decision-makers. The decision-makers can use linguistic variables both for the criteria and for the degree of satisfying them by contractors. The way in which linguistic variables, used by Singh and Tiong, are interpreted, has been applied in the model developed by the author and discussed in the paper.

\subsection{General characeristics OF THE MODEL}

The main purpose of the model is to choose a contractor for a concrete project ("per project"). In the assumed scheme, it is accepted that only contractors from the "standing list" can apply for the realization of the project. However, it is not an indispensable condition. The model can also be used for the evaluation of contractors, especially when there is no other form of preliminary selection. In such a case a greater number of general criteria should be considered, not only those connected with the project.

The model considers different objectives and criteria. The basic objectives considered in the model are time, cost, and quality of works. Evaluation is usually carried out by a team of decision makers. In the model there is a possibility of taking into consideration evaluations by many decision makers.

The advantage of the model is the fact that all evaluations can be presented in the form of linguistic values. Making use of the fuzzy sets theory, the linguistic variables are converted into fuzzy numbers. Fuzzy relations are formed, then fuzzy compositions determining the relationship between objective and contractor through their respective relationships to criterion.

As it results from the specificity of the model it is difficult to determine a satisfying evaluation. Thus, it is important that all the contractors are evaluated at the same time. The number of contractors evaluated as the best, who are qualified, should be in agreement with the number determined by the owner. A simultaneous evaluation of all candidates makes the task easier for the decision makers, who can compare the contractors' features.

In the model an algorithm is accepted:

1. In the first stage the construction owner has to define the objectives $\left(c_{m}\right)$ he wants to achieve in the project.

2. We determine $k_{n}$ criteria having influence on the decision on a contractor being qualified.

3. Decision-makers $\left(d_{p}\right)$ evaluate the degree to which the construction owner aims at achieving a given objective, the degree of criteria importance for the construction owner, and the degree of satisfying criteria by particular contractors. 
3.1. In the evaluation the decision-makers use linguistic variables: Linguistic variables (very important, important, above average, average, below average, less important, the least important), refer to the evaluation of the importance degree in reaching a given objective, and to the evaluation of a given criterion. Values of linguistic variables (very good, good, above average, average, below average, poor, very poor), refer to the evaluation of the degree of contractors satisfying the criterion.

3.2. Linguistic variables are converted into a fuzzy numbers (Fig. 2 and Table 1) (Singh, Tiong [34]).

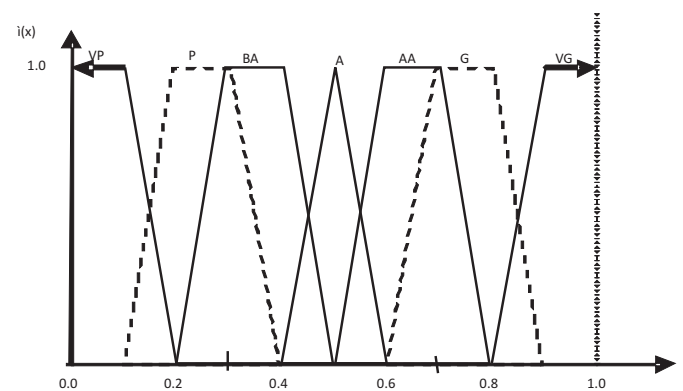

Fig. 2. Graphical representation of fuzzy numbers for linguistic variables. Rys. 2. Interpretacja rozmyta zmiennych lingwistycznych

Fuzzy numbers for linguistic variables.

Table 1 Interpretacja rozmyta zmiennych lingwistycznych

\begin{tabular}{|l|l|}
\hline Linguistic variables & Fuzzy numbers \\
\hline VG/VI very good/important & $(0.8,0.9,1.0,1.0)$ \\
\hline G/I good/important & $(0.6,0.7,0.8,0.9)$ \\
\hline AA above average & $(0.5,0.6,0.7,0.8)$ \\
\hline A average & $(0.4,0.5,0.5,0.6)$ \\
\hline BA below average & $(0.2,0.3,0.4,0.5)$ \\
\hline P/LI poor/low important & $(0.1,0.2,0.3,0.4)$ \\
\hline VP/VLI very poor/very low important & $(0.0,0.0,0.1,0.2)$ \\
\hline
\end{tabular}

3.3. For each objective we determine fuzzy value of the degree to which a construction owner is striving in order to reach a given objective 
$-C_{a j}^{k}-a(a=1,2, \ldots, m)$ objective evaluation, by $j(j=1,2, \ldots, p)$ decision-maker, for $e(e=1,2,3,4)$ variant

$$
C_{a j}^{\prime k}=\left[\begin{array}{cccc}
\left(C_{11}^{1}, C_{11}^{2}, C_{11}^{3}, C_{11}^{4}\right) & \left(C_{12}^{1}, C_{12}^{2}, C_{12}^{3}, C_{12}^{4}\right) & \ldots & \left(C_{1 p}^{1}, C_{1 p}^{2}, C_{1 p}^{3}, C_{1 p}^{4}\right) \\
\left(C_{21}^{1}, C_{21}^{2}, C_{21}^{3}, C_{21}^{4}\right) & \left(C_{22}^{1}, C_{22}^{2}, C_{22}^{3}, C_{22}^{4}\right) & \ldots & \left(C_{2 p}^{1}, C_{2 p}^{2}, C_{2 p}^{3}, C_{2 p}^{4}\right) \\
\cdot & & & \\
\left(C_{m 1}^{1}, C_{m 1}^{2}, C_{m 1}^{3}, C_{m 1}^{4}\right) & \left(C_{m 2}^{1}, C_{m 2}^{2}, C_{m 2}^{3}, C_{m 2}^{4}\right) & \ldots & \left(C_{m p}^{1}, C_{m p}^{2}, C_{m p}^{3}, C_{m p}^{4}\right)
\end{array}\right]
$$

The average score of decision-makers:

$C_{a j}^{\prime \prime k}=\left[\begin{array}{llll}\left(C_{11}^{1}+C_{12}^{1}+\ldots+C_{1 p}^{1}\right) / p & \left(C_{11}^{2}+C_{12}^{2}+\ldots+C_{1 p}^{2}\right) / p & \left(C_{11}^{3}+C_{12}^{3}+\ldots+C_{1 p}^{3}\right) / p & \left(C_{11}^{4}+C_{12}^{4}+\ldots+C_{1 p}^{4}\right) / p \\ \left(C_{21}^{1}+C_{22}^{1}+\ldots+C_{2 p}^{1}\right) / p & \left(C_{21}^{2}+C_{22}^{2}+\ldots+C_{2 p}^{2}\right) / p & \left(C_{21}^{3}+C_{22}^{3}+\ldots+C_{2 p}^{3}\right) / p & \left(C_{21}^{4}+C_{22}^{4}+\ldots+C_{2 p}^{4}\right) / p \\ & & & \\ \left(C_{m 1}^{1}+C_{m 2}^{1}+\ldots+C_{m p}^{1} / p\right. & \left(C_{m 1}^{2}+C_{m 2}^{2}+\ldots+C_{m p}^{2}\right) / p & \left(C_{m 1}^{3}+C_{m 2}^{3}+\ldots+C_{m p}^{3}\right) / p & \left(C_{m 1}^{4}+C_{m 2}^{4}+\ldots+C_{m p}^{4}\right) / p\end{array}\right]$

Introducing denotations:

$$
\begin{aligned}
\left(C_{11}^{1}+C_{12}^{1}+\ldots+C_{1 p}^{1}\right) / p & =C_{11} \\
\left(C_{11}^{2}+C_{12}^{2}+\ldots+C_{1 p}^{2}\right) / p & =C_{12} \\
\left(C_{11}^{3}+C_{12}^{3}+\ldots+C_{1 p}^{3}\right) / p & =C_{13} \\
\left(C_{11}^{4}+C_{12}^{4}+\ldots+C_{1 p}^{4}\right) / p & =C_{14} \\
\left(C_{21}^{1}+C_{22}^{1}+\ldots+C_{2 p}^{1}\right) / p & =C_{21} \\
\left(C_{21}^{2}+C_{22}^{2}+\ldots+C_{2 p}^{2}\right) / p & =C_{22} \\
\ldots & \\
\left(C_{m 1}^{3}+C_{m 2}^{3}+\ldots+C_{m p}^{3}\right) / p & =C_{m 3} \\
\left(C_{m 1}^{4}+C_{m 2}^{4}+\ldots+C_{m p}^{4}\right) / p & =C_{m 4} .
\end{aligned}
$$

Objective evaluation matrix is obtained:

$$
C_{a j}=\left[\begin{array}{cccc}
C_{11} & C_{12} & C_{13} & C_{14} \\
C_{21} & C_{22} & C_{23} & C_{24} \\
\cdot & & & \\
C_{m 1} & C_{m 2} & C_{m 3} & C_{m 4}
\end{array}\right] .
$$

3.4. The crisp score (defuzzified value) - the average degree to which a construction owner is striving in order to reach a given objective - is obtained as follows (Kaufmann and Gupta [35]):

$$
C_{a}=\left(C_{a 1}+C_{a 2}+C_{a 3}+C_{a 4}\right) / 4
$$


For details about different types of fuzzy numbers, membership function, aggregation, and defuzzification methods, interested readers are referred to Klir and Folger [36], Kaufmann and Gupta [35], Kacprzyk [37].

Next, similarly to the case of the degree to which a construction owner is striving in order to reach a given objective, the degree of criterion importance and degree of satisfying criteria by particular contractors is established.

3.5. For each criterion we determine fuzzy value of the degree of criteria importance for the construction owner

$K_{b j}^{k}-b(b=1,2, \ldots, n)$ criterion evaluation by $j(j=1,2, \ldots, p)$ decision-maker, for $e(e=1,2,3,4)$ variant;

$n$ - number of criteria.

Criteria evaluation matrix: $K_{b j}$.

3.6. The crisp score (defuzzified value) - the average degree of criteria importance for the construction owner: $K_{b}$.

3.7. For each contractor we determine, fuzzy value of satisfying criteria by particular contractors

$W_{c j b}^{e}-c(c=1,2, \ldots, t)$ contractor evaluation, by $j$ decision maker, for $e$ variant, according to $b$ criterion;

$t$ - number of contractors.

Contractor evaluation matrix: $W_{c j b}$.

3.8. The crisp score (defuzzified value) - the average degree of satisfying criteria by particular contractor: $W_{c b}$

4. The elements of the $R(c, k)$ relation are calculated, where $R(c, k)$ is a fuzzy binary relation approximating the relationship between the objective set and criteria set:

$$
R\left(c_{a}, k_{b}\right)=C_{a} \times K_{b} \times I_{a b} .
$$

where: $I_{a b}$ - influence of $b$ criterion on $a$ objective;

5. The elements of the $R(k, w)$ relation are calculated, where $R(k, w)$ is a fuzzy binary relation. Each element of $R(k, w)$ represents the degree of satisfying criteria by particular contractors.

6. The elements of the $Q(c, w)$ relation are calculated, where $Q(c, w)$ is a fuzzy composition operation, performed on the 2 fuzzy binary relations $R(c, k)$ and $R(k, w)$. The elements of the $Q(c, w)$ relation determine the relationship between objective $c$ and contractor $w$ through their respective relationships to criterion $k$. We use maximum-minimum (max-min) and cumulative-minimum (cum-min) composition operation.

- The max-min operation is defined, for a given $c_{a}$ and $w_{c}$, by (Klir and Folger [36]:

$$
Q(c, w)=S \circ R\left(c_{a}, w_{c}\right)=\max \min \left[R\left(c_{a}, k_{b}\right), R\left(k_{b}, w_{c}\right)\right] \text { for all } k_{b} .
$$

Contractor evaluation is obtained as follows:

$$
O_{i}=\left[\sum Q\left(c_{a}, w_{c}\right)\right] / \sum c_{a} \text { for } a=1 \text { to } m .
$$


- The cum-min operation is defined, for a given $c_{a}$ and $w_{c}$, by (Russel and Fayek [38]):

$$
Q(c, w)=S \circ R\left(c_{a}, w_{c}\right)=\operatorname{sum} \min \left[R\left(c_{a}, k_{b}\right), R\left(k_{b}, w_{c}\right)\right] \text { for all } k_{b} .
$$

Contractor evaluation is obtained using Eq. (6.5).

A detailed description of the model can be found in [39].

\subsection{ANALYSES OF MODEL SENSITIVITY}

In order to examine the influence of particular input data on the results of operations performed on the model, a sensitivity analysis was carried out. One of the input data was changed, assuming that the remaining data were stable. The influence of these changes on the final result was observed. Model sensitivity measure is a variation of the final results in answer to the changes in particular parameters of the input data.

In the carried out analysis, the influence of the following parameter variations on the evaluation of the contractor was examined:

- the degree to which the construction owner aims at achieving a given objective,

- the number of objectives,

- the degree of criteria importance for the construction owner,

- the degree of satisfying criteria by particular contractors,

- the number of criteria,

- the degree to which the criterion influences of on objective.

The carried out analyses aimed at establishing some general tendencies of the model behavior. On the basis of the carried out analyses some general conclusions can be made about the input data influence on the final results:

1) The degree of criterion importance has the biggest influence on the final results for the owner. Slightly less important is the degree of satisfying the criteria by particular contractors. The degree to which the construction owner aims at achieving a given objective, and the value of coefficient $I_{a b}$, only slightly influences on final results.

2) Greater influence of the input data on the final results can be seen in the sum-min method than in the max-min one.

3) Introduction of additional objectives or criteria only slightly influences on the final results (a little bit more when introducing additional criteria).

\section{3. "Prequalification" programme}

As an aid in prequalification procedure and model usage, the author worked out a software with a working name "Prequalification". It can be used in the most popular systems in Poland, such as Microsoft Windows XP, Vista and Windows 7. The program is in Polish. It is meant for a particular owner, but after some modifications, especially those referring to prequalification onto a "standing list", it can be used by any owner. The aim of the software is to make it easier for the owner to evaluate the contractors 
onto the "standing list", and then to choose one for a concrete project from among them. In the prequalification "per project", a mathematical model presented in the paper was used. The software is divided into two fundamental parts - the modulus of the contractor and that one of the owner. In the contractor modulus, a candidate for the "standing" and then "short list" has to provide the data demanded by the owner. The data are determined by the owner as the needs arise, and passed on to the contractor in the form to be filled up.

Modulus of the owner is much more elaborated. It consists of three fundamental parts - the first allows to evaluate a contractor onto the "standing list", the next enables to prepare data concerning the realized project, the third allows to evaluate "per project" contractors. Additionally, the software ensures indispensable contact between the owner and contractors - transmitting data, inquiries, and supplementing information.

Further, only a part of the software that allows the owner to evaluate "per project" contractor will be discussed.

The selection of contractors for a specific project is possible thanks to a form for "per project evaluation", available in the owner modulus. This function makes it possible for a decision maker to add evaluation, remove it, and recalculate it, and thus gain contractors ranking. (Fig. 3)

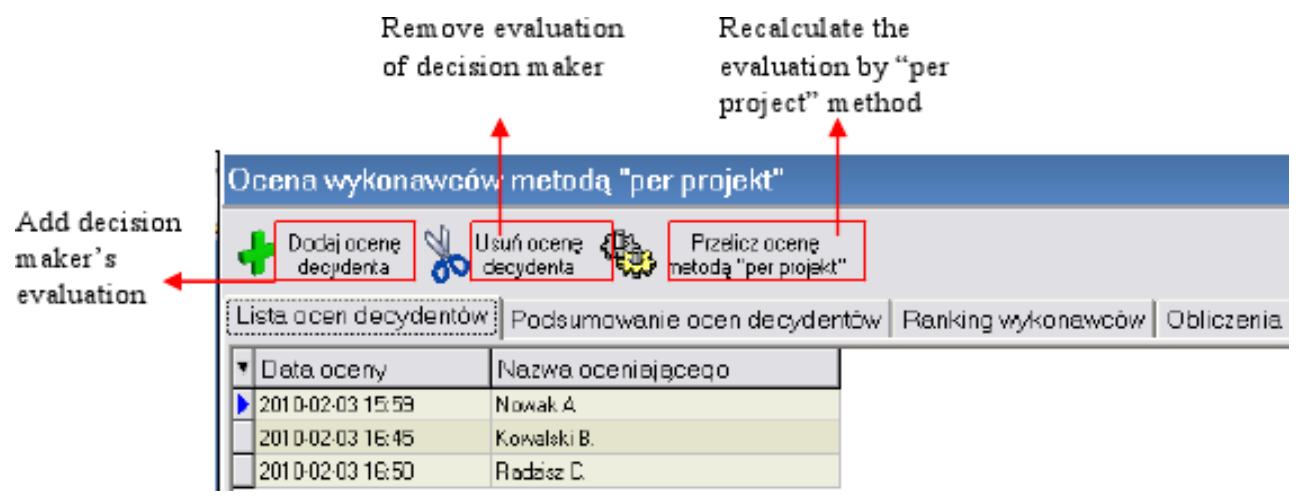

Fig. 3. Form for "per project evaluation".

Rys. 3. Formularz „ocena wykonawców metodą per projekt”

To evaluate contractors for a given, earlier determined project, a decision maker has to click "add decision maker's evaluation" button. Objectives considered in the project appear as the first, for them the degree the owner wants to achieve is then evaluated. Ascription of the evaluation takes place when a particular objective is marked in the table, evaluation value chosen from the lower panel, and evaluation ascribed by pressing "ascribe evaluation" button. (Fig. 4) 


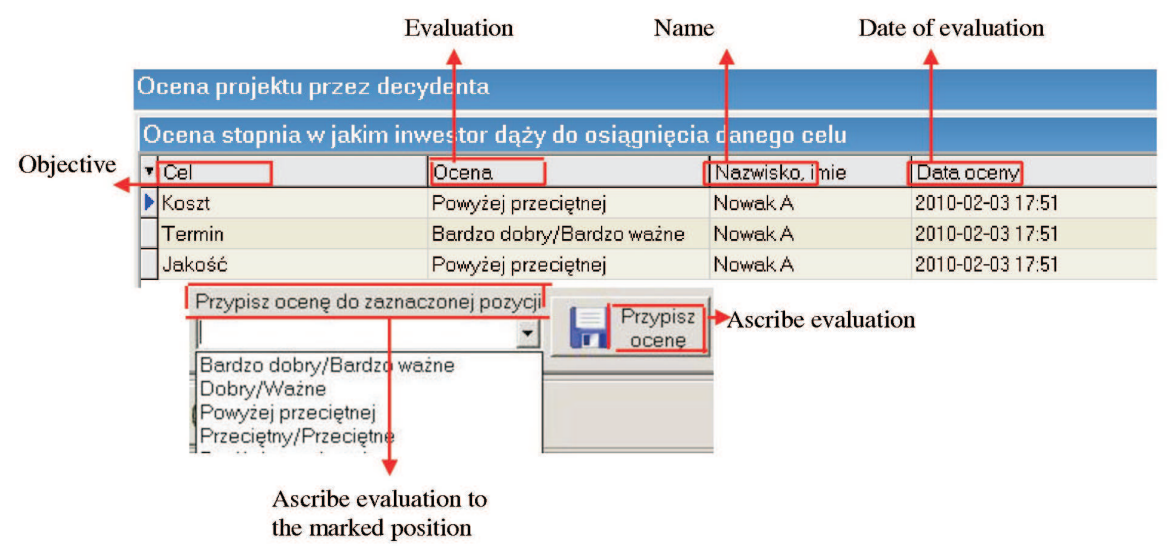

Fig. 4. Evaluation of the degree to which the objective is desired by the owner. Rys. 4. Ocena stopnia w jakim inwestor dąży do osiągnięcia danego celu

In the next step, having pressed the button "accept", there the evaluation of the degree of criteria importance follows. The evaluation is done identically as in the previous step. (Fig. 5)

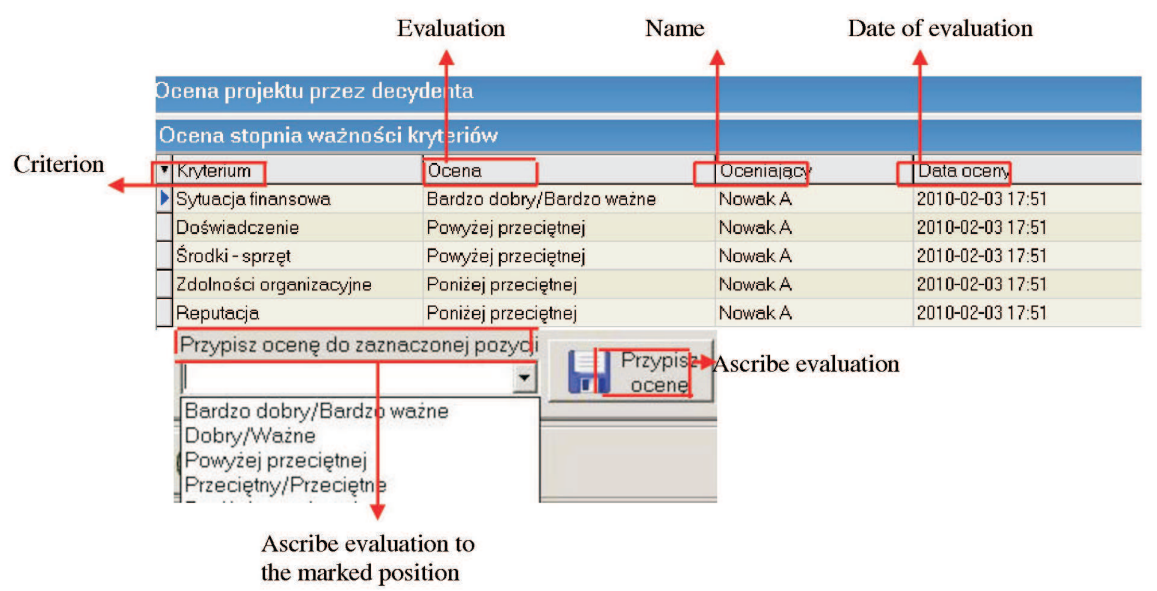

Fig. 5. Evaluation of the degree of the importance of criteria.

Rys. 5. Ocena stopnia ważności kryteriów

The last step of evaluation by the decision maker is to evaluate the degree of satisfying criteria by particular contractors. The only difference, in comparison to previous steps of evaluation, is an additional criterion from the list developed in relation to the choice of a contractor from the list. (Fig. 6) At each stage of contractor evaluation, the decision maker has an access to the candidate's data. 


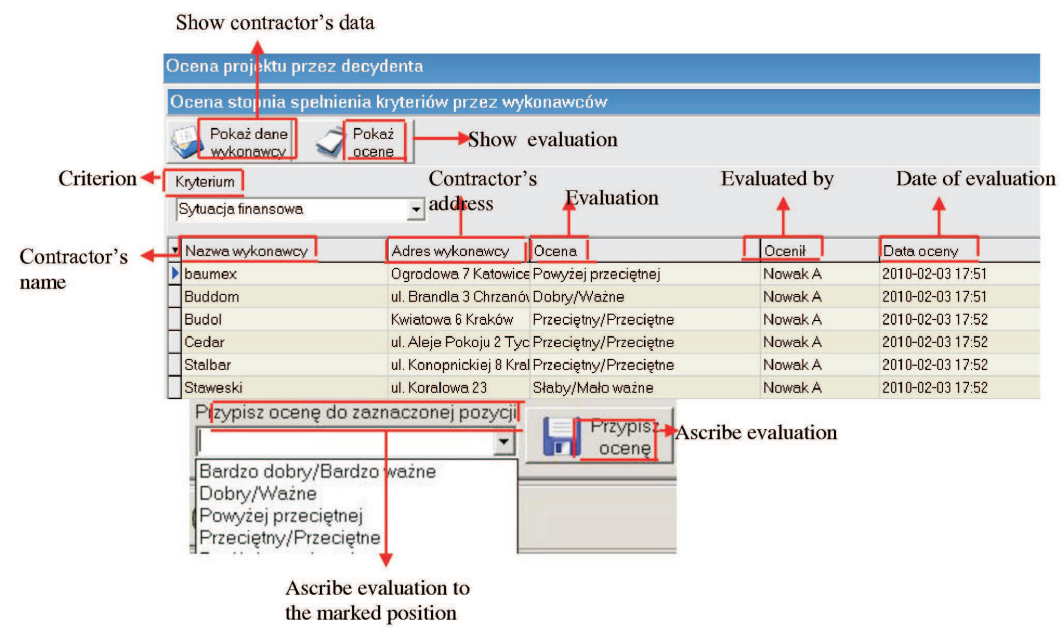

Fig. 6. Evaluation of fulfilling the criteria by contractors.

Rys. 6. Ocena stopnia spełnienia kryteriów przez wykonawców

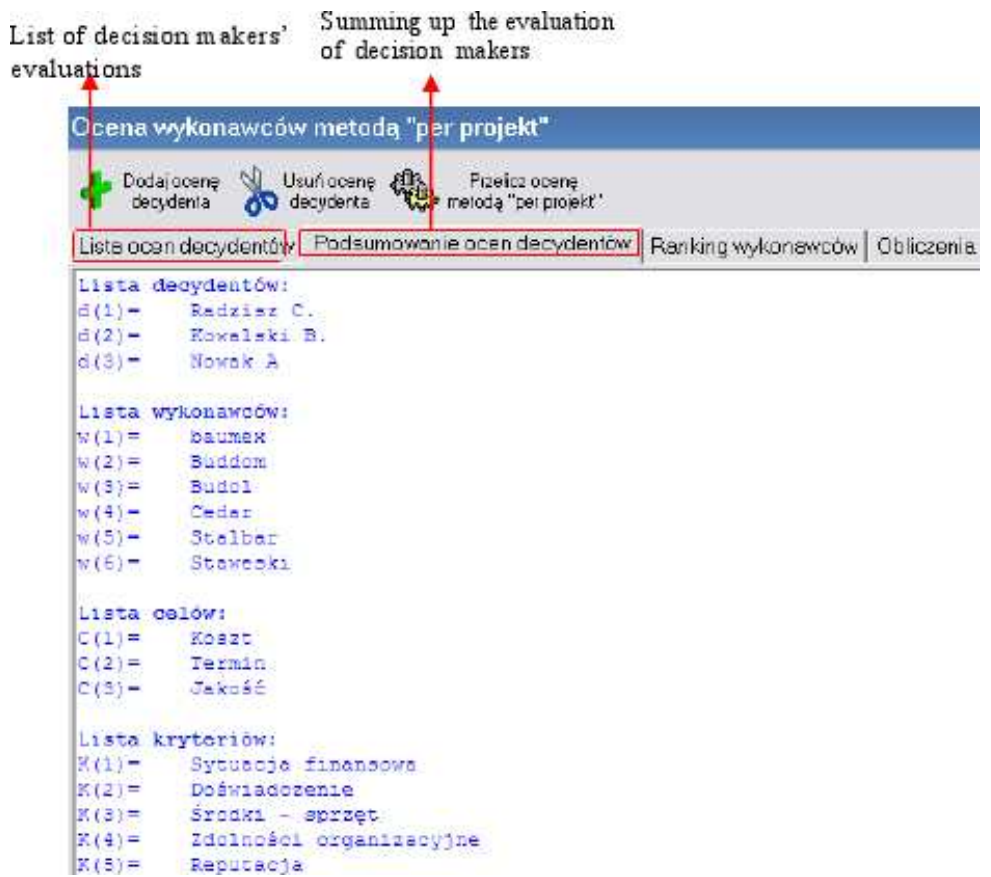

Fig. 7. Bookmark "summarising the evaluation of the decision makers". Rys. 7. Zakładka ,podsumowanie ocen decydentów" 
Evaluation of the project is calculated after pressing the button "calculate evaluation by per project method". In the first bookmark on the form for "per project evaluation" there is a list of decision makers' evaluations. In the subsequent bookmark there is decision makers' summing up of the evaluation. (Fig. 7)

The next bookmark contains ranking of the contractors. (Fig. 8)

\begin{tabular}{|c|c|c|c|}
\hline \multicolumn{4}{|c|}{$\begin{array}{l}\text { Contractors } \\
\text { ranking }\end{array}$} \\
\hline \multicolumn{4}{|c|}{ Ocena wykonawców metodą "per projekt" } \\
\hline \multicolumn{3}{|c|}{ 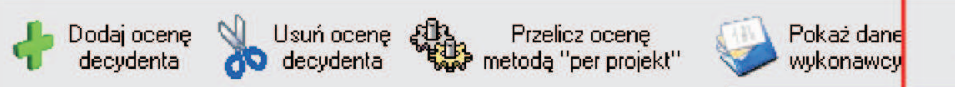 } & 2 Pokaż \\
\hline \multicolumn{4}{|c|}{ Lista ocen decydentów | Podsumowanie ocen decydentów Rank } \\
\hline Nazwa wykonawcy & Adres wykonawcy & $\begin{array}{l}\text { Ocena } \\
\text { metodą } \\
\text { MAX-MIN }\end{array}$ & \begin{tabular}{|l|} 
Ocena \\
metodá \\
SUM-MIN
\end{tabular} \\
\hline baumex & Dgrodowa 7 Katowice & 0.925 & 2,96 \\
\hline Budol & Kwiatowa 6 Krakóm & 0,905 & 2.92 \\
\hline Buddom & ul. Brandla 3 Chrzanów & 0,902 & 2,96 \\
\hline Stalbat & ul. Konoprickiej 8 Krakóm & 0.881 & 2,94 \\
\hline Staweski & ul. Koralowa 23 & 0.799 & 2.82 \\
\hline Cedar & ul. Aleje Pokoju 2 Tychy & 0.71 & 2,68 \\
\hline
\end{tabular}

Fig. 8. Bookmark "contractors ranking".

Rys. 8. Zakładka „ranking wykonawców”

\section{Conclusions}

In the paper prequalification models of contractors for construction works are briefly characterized. The model built on the basis of fuzzy sets theory is presented in a more detailed way. Sensitivity analysis of the model allows to evaluate the input data influence on the obtained results. As an aid in practical application of the procedure of selecting contractors, the author has worked out the "Prequalification" software. The paper describes part of the programme applying the earlier presented mathematical model.

\section{REFERENCES}

1. E. Palaneeswaran, M. Kumaraswamy, Recent advances and proposed improvements in contractor prequalification methodologies, Building and Environment, 36, 73-87, 2001. 
2. N. BANAITIENË, A. BANAitis, Analysis of criteria for contractors' qualification evaluation, Technological and Economic Development of Economy, 12, 4, 276-282, 2006.

3. P. Jennings, G.D. Holt, Prequalification and multi-criteria selection: a measure of contractors' opinions, Construction Management and Economics, 16, 651-660, 1998.

4. S. Mitkus, E. TrinKÚNIENË, Analysis of criteria system model for construction contract evaluation, Technological and Economic Development of Economy, 13, 3, 244-252, 2007.

5. E. Plebankiewicz, Construction Contractor Prequalification from Polish Clients' Perspective, Journal of Civil Engineering and Management, 16, 1, 57-64, 2010.

6. J.S. Russell, Decision models for analysis and evaluation of construction contractors, Construction Management and Economics, 10, 185-202, 1992.

7. D. Singh, R.L.K. Tiong, Contractor selection criteria: investigation of opinions of Singapore construction practitioners, Journal of Construction Engineering and Management, 132, 9, 998-1008, 2006.

8. F. WAara, J. Brochner, Price and nonprice criteria for contractor selection, Journal of Construction Engineering and Management, 132, 8, 797-804, 2006.

9. E.J. JASELSKIS, J.S. RusSELl, An efficient structured approach for selection of most promising construction contractors, Project Management Journal, 12, 4, 31-39, 1991.

10. K.J. Arrow, Bayes and minimum solution of sequential decision problems, Econometrica, 213-243, 1949.

11. J.S. Russell, Decision models for analysis and evaluation of construction contractors, Construction Management and Economics, 10, 185-202, 1992.

12. J.S. Russell, M.J. SkiBniewski, QUALIFIER-1: Contractor prequalification model, Journal of Computing in Civil Engineering, 4, 1, 77-90, 1990.

13. K.M. Al-Harbi, Application of the AHP in project management, International Journal of Project Management, 19, 19-27, 2001.

14. T.L. SaAty, How to make a decision: the analytic hierarchy process, European Journal of Operational Research, 40, 9-26, 1990.

15. P. Fong SiK-Wah, S. Chо KIT-Young, Final contractor selection using the analytical hierarchy process, Construction Management and Economics, 18, 547-557, 2000.

16. I.M. Mahd, M.J. Riley, S.M. Fereig, A.P. Alex, A multi-criteria approach to contractor selection, Engineering, Construction and Architectural Management, 9, 1, 29-37, 2002.

17. E. Plebankiewicz, Selected models of initial selection of construction contractors [in Polish], Przegląd Budowlany, 04, 47-51, 2008.

18. J.S. Russell, M.J. SKIBNIEwSKi, D.R. CozIER, QUALIFIER-2: Knowledge-based system for contractor prequalification, Journal of Construction Engineering and Management, 116, 1, 157-171, 1990.

19. K.C. Lam, T. Hu, S.T. NG, M. Skitmore, S.O. Cheung, A fuzzy neural network approach for contractor prequalification, Construction Management and Economics, 19, 175-180, 2001.

20. F. Kноsвошннані, Neural network model for contractors' prequalification for local authority projects, Engineering, Construction and Architectual Management, 6, 3, 315-328, 1999.

21. A.M. Elazouni, Classifying construction contractors using unsupervised-learning neural networks, Journal of Construction Engineering and Management, 132, 12, 1242-1253, 2006.

22. E.K. Zavadskas, T. ViLutienë, A multiple criteria evaluation of multi-family apartment block's maintenance contractors: I - Model for maintenance contractor evaluation and the determination of its selection criteria, Building and Environment, 41, 5, 621-632, 2006.

23. E.K. Zavadskas, R. Litas, Z. Turskis, Multi-attribute decision-making methods for assessment of quality in bridges and road construction: state-of-the-art surveys, The Baltic Journal of Road and Bridge Engineering, 3, 3, 152-160, 2008. 
24. E.K. Zavadskas, A. Kaklauskas, F. Peldschus, Z. Turskis, Multi-attribute assessment of road design solutions by using the COPRAS method, The Baltic Journal of Road and Bridge Engineering, 2, 4, 195-203, 2007.

25. P. JАŚKоWSKI, Designing the structure of a construction project operating system using evolutionary algorithm, Archives of Civil Engineering, 54, 2, 371-394, 2008.

26. W.K.M. Brauers, E.K. Zavadskas, Z. Turskis, T. Vilutienë, Multi-objective contractor's ranking by applying the MOORA method, Journal of Business Economics and Management, 9, 4, 245-255, 2008.

27. R. Ginevičıus, V. Podvezko, Multicriteria graphical-analytical evaluation of the financial state of construction enterprises, Technological and Economic Development of Economy, 14, 4, 452-461, 2008.

28. S. Mitkus, E. TrinkÛNienë, Reasoned decisions in construction contracts evaluation, Technological and Economic Development of Economy, 14, 3, 402-416, 2008.

29. Z. TURSKIs, Multi-attribute contractors ranking method by applying ordering of feasible alternatives of solutions in terms of preferability technique, Technological and Economic Development of Economy, 14, 2, 224-239, 2008.

30. E.K. Zavadskas, Z. Turskis, J. Tamošaitienë, Contractor selection of construction in a competitive environment, Journal of Business Economics and Management, 9, 3, 181-187, 2008.

31. E.K. Zavadskas, T. Vilutiene, Z. Turskis, J. Tamosaitiene, Contractor selection for construction works by applying saw-g and topsis grey techniques, Journal of Business Economics and Management, 11, $1,34-55,2010$.

32. L.H. ZADEH, Fuzzy sets, Information and Control, 8, 3, 338-353, 1965.

33. V.U. NGUYen, Tender evaluation by fuzzy sets, Journal of Construction Engineering and Management, 111, 231-243, 1985.

34. D. Singh, R.L.K. Tiong, A fuzzy decision framework for contractor selection, Journal of Construction Engineering and Management, 131, 1, 62-70, 2005.

35. A. Kaufmann, M.M. Gupta, Introduction to fuzzy arithmetic theory and application, Van Nostrand Reinhold, New York 1991

36. G.J. KliR, T.A. Folger, Fuzzy sets, uncertainty and information, Prentice-Hall, Englewood Cliffs, N. J. 1988.

37. J. Kacprzyк, Fuzzy Sets in Systems Analysis, PWN, Warszawa 1986.

38. J.S. Russel, A. FAYEK, Automated corrective action selection assistant, Journal of Construction Engineering and Management, ASCE, 120, 1, 11-33, 1994.

39. E. Plebankiewicz, Contractor prequalification model using fuzzy sets, Journal of Civil Engineering and Management, 15, 4, 377-385, 2009.

Choosing a construction contractor is one of the most important decisions made by an owner. Using the prequalification procedure makes it possible to select the most competent tenderers. Various mathematical models are helpful in carrying out prequalification procedure. The paper briefly characterizes simple mathematical models, such as dimensional weighting model, linear model, or models taking into consideration many evaluation variants. Among the models built on the basis of a complex mathematical method is the model making use of AHP described in the paper. All characterized models have certain limitations. In the paper, the author offers her own model in which fuzzy sets theory is applied. The model takes into consideration various objectives of the owner, as well as different criteria for evaluation of contractors, also many evaluations of decision makers are possible. The advantage of the model is that all evaluations can be presented in the form of linguistic variables. Making use of the theory of fuzzy sets, linguistic variables can be transformed into a fuzzy numbers. On the basis of sensitivity analysis of 
the model, some general conclusions can be formed in reference to the influence of input data on final results. It appears that for the owner, the degree of criteria importance has the biggest influence on the final results. As an aid in application of the procedure, the author has worked out a programme of the working name "Prequalification". The aim of the programme is to make it easier for the owner to evaluate contractors onto a "standing list", and then to choose from among them contractors for a specific project. In "per project" prequalification procedure, a mathematical model presented in the paper was used. The paper describes this part of the programme which allows the owner to evaluate "per project" contractor.

\section{Streszczenie}

Wybór wykonawcy robót budowlanych jest jedną z najważniejszych decyzji podejmowanych przez inwestora. Zastosowanie procedury prekwalifikacji daje szansę wyselekcjonowania najbardziej kompetentnych oferentów. Przeprowadzenie procedury prekwalifikacji wspomagają różnego rodzaju modele matematyczne. W artykule krótko scharakteryzowano proste modele matematyczne, takie jak model wagowy, liniowy, modele uwzględniające wiele wariantów oceny. Do modeli zbudowanych w oparciu o złożony aparat matematyczny można zaliczyć, omówiony w artykule model wykorzystujący AHP. Wszystkie scharakteryzowane modele posiadają pewne ograniczania. W artykule zaproponowano także własny model, wykorzystujący teorię zbiorów rozmytych. Zastosowany model uwzględnia zarówno różne cele stawiane sobie przez zamawiającego jak i różne kryteria oceny wykonawców a także oceny wielu decydentów. Zaletą modelu jest fakt, że wszystkie oceny zamawiający mogą przedstawić w formie wartości lingwistycznych. Wykorzystując założenia teorii zbiorów rozmytych, wartości lingwistyczne przekształcane są do formy rozmytej. Na podstawie przeprowadzonej analizy wrażliwości modelu, można wyciągnąć pewne ogólne wnioski, odnośnie wpływu danych wejściowych na końcowe wyniki. Wynika z niej, że największy wpływ na końcowe wyniki ma stopień ważności kryteriów dla zamawiającego. Jako pomoc w zastosowaniu procedury i modelu prekwalifikacji autorka opracowała program pod roboczą nazwą „Prekwalifikacja”. Celem programu jest ułatwienie zamawiającemu oceny wykonawców na „stałą listę”, a następnie wybór z ich grona wykonawców do konkretnego przedsięwzięcia. W procedurze prekwalifikacji „per project” zastosowano model matematyczny zaprezentowany w artykule. W artykule opisano część programu umożliwiającą inwestorowi ocenę wykonawcy ,per project”.

Remarks on the paper should be sent to the Editorial Office

no later than March 30, 2011
Received April 25, 2010 revised version

December 15, 2010 